\title{
Fading Legacy of the Architectural Heritage of the Historic Core of Karachi
}

\author{
Tania Ali Soomro \\ Department of Architecture and \\ Planning \\ Dawood University of Engineering \& \\ Technology \\ Karachi, Pakistan
}

\author{
Mohsin Ali Soomro \\ Department of Civil Engineering \\ Quaid-e-Awam University of \\ Engineering, Science \& Technology \\ Nawabshah, Pakistan \\ drmohsin@quest.edu.pk
}

\author{
Abdul Nasir Laghari \\ Department of Chemical Engineering \\ Quaid-e-Awam University of \\ Engineering, Science \& Technology \\ Nawabshah, Pakistan
}

\author{
Daddan K. Bangwar \\ Department of Civil Engineering \\ Quaid-e-Awam University of Engineering, Science \& \\ Technology \\ Nawabshah, Pakistan
}

\author{
Mukhtiar Ali Soomro \\ Department of Civil Engineering \\ Quaid-e-Awam University of Engineering, Science \& \\ Technology \\ Nawabshah, Pakistan
}

\begin{abstract}
In 1839 British East India Company captured the town of Karachi. After an effortless resistance from the locals the fort was conquered by the British commander sir Charles Napier. The village of Kolachi then was annexed to British India and the city was labeled as Karachi. With the British occupation a phase of new sophisticated architecture and development started. Before that the city was based upon the vernacular mud architecture. These developments resulted in an influx of economic migrants who helped in making Karachi as a multinational and a multicultural city. This paper investigates the architectural attributes that the historic core of the city offers. It also discusses the side by side development of the native and British towns. The paper also researches about the existing state of the architecture precedent of the British colonial past of the city and the urban blight occurred to them over time in various forms like vandalism, encroachments, illegal repairs, etc.
\end{abstract}

Keywords-architecture; Karachi; legacy; urban; development

\section{INTRODUCTION}

The city of Karachi was established in 1729 as a fortified port settlement which used to be part of the greater British Raj together with the present day countries of India and Bangladesh. Although the city is only 250 years old, there are places of pilgrimage within that go back to more than 2000 years. Most of them are still active [1]. Karachi used to be a small fishing village at the time when it was occupied by the British in 1839 and with this annexation a new era of development and construction started. Karachi remained a British colony from 1839 to 1947 for 108 years. In 1843 the whole province of Sindh was captured by British and Karachi was made its capital. New business opened up with the development of its harbor for shipping. The foundations of a city municipal government were laid down and infrastructure development was undertaken. At that time, the British realized the significance of the city as a military cantonment and laid foundation of a new division. The cantonment was a mock-up of an English industrial parent-city, in other words, a basis of the 'white' town, where the local population had restricted rights of entry, where work and residential spaces were separated [2]. At present day the city is divided into 6 different zones and each of the zones is divided further into towns/municipalities. Altogether there are 18 elected municipal administrations for infrastructure and spatial planning, development facilitation, and municipal services with some functions being retained by the KMC. The towns are further sub-divided into 178 localities (each town has its own number of localities).

\section{INTRODUCTION TO THE HISTORIC CORE OF KARACHI}

Historically, the city was divided into 18 different quarters as it grew after the British annexation (demarcated by Alexander F. Bailie, the municipal engineer then). These 18 parts are now referred to as the historic core or the center of the city. Among 18 quarters, 13 are closely located and the rest are located at a distance. The boundaries of these quarters do not usually coincide with the town boundaries. Therefore, the Saddar Town and the Saddar Bazaar quarter should not be confused to be the same. These quarters contain much of the oldest parts of the city which signifies the colonial history of Karachi, in particular the Saddar Bazaar and the neighboring areas of Kharadar and Mithadar. The town is further subdivided in 11 municipal localities, including Saddar Bazaar as one of the locality. The present day historic center was developed by the British during the colonial era and housed magnificent 
structures of great importance. It became a highly fashionable district of the city with Saddar as the main market place. The word Saddar is derived from Arabic which means chief, main or the supreme and it developed as a bazaar that ultimately became a main bazaar of the town, not only as a market of stalls under one roof, but it grew as a sophisticated neighborhood containing a number of stores and shops [3]. Author in [3] remembers Saddar as the most sophisticated and well planned settlement having wide stone paved streets set of grid iron patterns with proper pedestrian and vehicular traffic demarcations. He mentions about few of the landmark structures within that area specifically the Cunynghame Market (demolished later, location unknown probably situated on the eastern end of the Bazaar), built in 1861, at a cost of 17,500 rupees and the Parsi infant school. Preedy quarter that is located along the southeast (front) side of the Saddar Bazaar is named after the first 'Bazaar Master' of Karachi [2]. It houses some of the very important structures including the magnificent Scotch Presbyterian church, known as St. Andrew's and Bai Vir Baijee Soopariwalla Parsi (BVS) Boys high school. Another quarter is Artillery Maidan which is located to the northwest (back) side of the Saddar Bazaar. It used to house a military arsenal that was located in the north - east corner with access from preedy Street. During the late $1880 \mathrm{~s}$, one part of the quarter was dedicated to the horse keeper's lines, gun sheds, some cells for detention and a small hospital and rest of the quarter was just a large ground. Later that empty part was allocated for government purposes, and a number of government administrative buildings were built there including the Sindh Assembly Building, High court building and a number of embassies [2].

Cantonment from the southeast to the northeast side of the Saddar Bazaar was developed shortly after the British conquest of Sindh. It was essentially the domain of the British army, containing all building types necessary for their comfort, including British army officer's residential colony, junior officers, British/native administration, residential lines, schools, hospitals, churches, canteens, stores, parade ground, an observatory etc. One of the magnificent structures is the St. Patrick's Cathedral and the School complex. These quarters are connected and accessed well by other localities via a public transportation system. There used to be a tram system which was discontinued during the 1960s. As a matter of fact, the trams were considered a traffic hazard as they stopped in the middle of the road [4]. Moreover these quarters are a harmonic mix of the people from various religious groups which is evident from the presence of mosques, church, Hindu and a Zoroastrian fire temple within them. The rich architectural heritage consists of both private and public premises such as apartments, mansions, institutions of dispensary, schools, office libraries etc. At present, the quarters are well connected with the rest of the city but unlike their original state, even though historic properties have gone through drastic changes. To understand the present conservation state of the heritage properties a survey is conducted and a mapping of the current state is developed. The scope of the exercise was originally supposed to be extended to the Saddar Bazaar and its adjoining quarters but due to constraint of time, it was limited to the Saddar Bazaar quarter only. The survey shows that the majority of the buildings, almost $60 \%$ of them, are partly maintained. A small number of buildings fall under the category of 'well maintained'. The degree of the maintenance is relative to the condition of the rest of the buildings in the quarter. However, it should not be considered as a perfectly restored condition, but, rather a state that is distinguishing from other buildings. Few historic buildings have been demolished over the period of time. A few of them have newly constructed structures and a few are under construction. A certain number of buildings are seen as having just standing facades of the original properties. Such type of buildings are identified as the "highly deteriorated', they are in a highly vandalized state and under high threats of complete demolition (Figure 1).

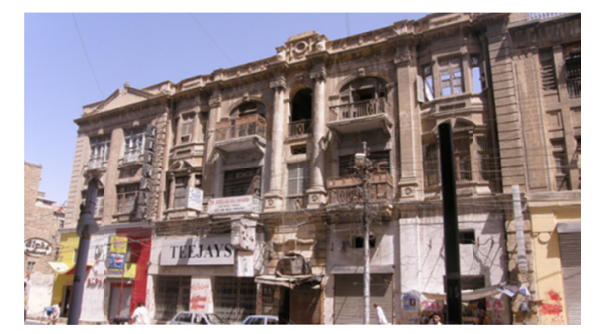

Fig. 1. Krishna Mansion in Saddar Bazaar (highly deteriorated)

\section{ARCHITECTURAL ANALYSIS OF THE HISTORIC CORE}

\section{A. Description of the Colonial Architecture of Karachi}

Anglo vernacular, colonial or the domestic gothic are the frequent terminologies by which the pre independence architecture (prior to 1947) of Karachi is referred to. These styles imitate a certain type of architectural approach popular in then contemporary Europe, particularly in England, adopted with the regional context of the area. As far as the city planning is concerned, there is no concept of the parallel planning identified in Karachi. This could be because the city developed more as a response to the growing needs in many unplanned ways rather than a planned scheme. With the development of the city as a port town in late $19^{\text {th }}$ and early $20^{\text {th }}$ century, Karachi became a dynamic commercial center. This attracted builders, masons, craftsmen and others from different regions to travel to Karachi to avail the work opportunities. Such approach is reflected in the hybrid architectural approach in form of an innovative mix of imported and regional forms to the built environment of Karachi. Parsi families who migrated to Karachi played their part as the great builders and the philanthropist - the qualities for which the community was already well-known in Bombay [2]. They built impressive edifices inspired by the European forms.

The most frequent recurring architectural attributes of the colonial period are the arcaded colonnaded porticos and openings, recessed windows, crowning cornices that project out to the certain level and the use of pilasters and sometimes the pediments. Regional features include Jodhpuri style turrets, grill iron works and the ornamentation in floral patterns. Lattice work in fine wood strips and the intricate concrete mashrabiyas are often seen with the semicircular gothic arched openings. Gizri stone as a main building component, in dressed surface finish, is most commonly seen. Moreover most sources have 
also quoted the late $19^{\text {th }}$ - early $20^{\text {th }}$ century architecture as the Italian Renaissance architectural approach. The use of colonnaded porticos, vestibules and courtyards are seen common in the buildings constructed during this phase such as the buildings of Mitharam hostel, Sewajunj, Mendoza and the KatrakParsi Mansion. Though the churches are not that ornamental as they are in Italy, but in certain ways, they do demonstrate a blend of the Renaissance forms used with respect to the regional context of Karachi. The foremost innovation of the Italian Romanesque architecture appropriately used here is the 'vault'. Vaults and arches and the sound knowledge of using them together, helped the colonial administrators to achieve extraordinary accomplishment in the construction of magnificent structures. The colonial administrators not only emphasized on the built structure but also executed some of the public works such as the water supply system for the settlements, sewerage and drainage systems, road networks and public transportation facility in the form of Tram. Author in [4] has elaborated the system of lighting. He has expressed that the city is lightened by the oil lamps every night. He has further added that approximate a thousand lamps are installed in the roads and streets, covering a length of over 60 miles, for which, since 1870, coconut oil is exchanged for kerosene oil in the lamps.

\section{CHRONOLOGICAL DEVELOPMENT}

Today's metropolitan city was founded by the local Baloch tribes from Balochistan and Makran as a small fishing village and was named Kolachi. It was ruled by the Talpur dynasty, one of the ruling dynasties in the province of Sindh before the British conquest. The village developed into a small port township and by late 1720 s, it started trading across the Arabian sea with Oman and Persian gulf. The town was fortified by a fort built by the local Sindhi populace. The fort had two entrances, one facing the sea, known as Kharra Darwaaza (brackish gate) and other facing the Lyari river known as Meetha Darwaaza (sweet gate because of sweet water of the river). The fort does not exist anymore but the old town area is still referred to as Kharradar and Meethadar. With the conquest of Karachi a new phase of architectural development arose and the village upgraded to a city. Colonial administrators established European inhabited quarters, and built stone structures. They also set up a number of public works of sanitation and transportation, such as gravel paved streets, proper drains, street sweepers, and a network of trams and horse-drawn trolleys, etc. One downside was that most of these amenities were only accessible by the British or some of the elite. Native people were deprived of such facilities.

The British built separate settlements next to the native walled city of Kolachi and clearly created a bifurcation as the native city and the British neighborhoods. The native city was close to the port and consisted of the old pre-British town and its suburbs. It was extremely congested and highly densified covering every bit of space with narrow streets for maneuvering. Due to the dense development in the town, there was less space for vegetation. As it was dominated by both Hindu and Muslim merchants as well as the working class, the architecture was a mix of low mud hovels and tall mud houses. Most often the houses were made of windowless mud walls with flat roofs. Bad-girs or the ventilators (wind catchers) surrounded by a tumble-down curtain-cum-bastions of mud, built upon humble platform of mud-covered rock was the significant architectural feature [5]. It contained most of the wholesale markets of the city. British city consisted of the cantonment, civil lines and the Saddar Bazaar quarters. The most part was inhabited by the British population. A large group of Parsi and Goan elite came to settle down in the British city. It contained posh retail markets, shops and eating places very similar to those in Europe (the members of these communities who still remain have become cultural minorities). This part of Karachi developed as a thinly populated low-rise settlement, with wide thoroughfares, green spaces and little plantation. Saddar Bazaar, one of the quarters of British neighborhood was created in 1839 immediately after the occupation of Karachi as a competitor to the wholesale markets in the native city. However, after the British annexation of Sindh in 1843, it evolved as a retail market for the European population of Karachi which consisted mainly of civil servants and military personnel [5]. Over time, Europeanized Indian communities made Saddar their home. At the time of partition Karachi was clearly divided into two: European city and native city. With further development, the city over flown the boundaries of British town and extended in all the directions having new colonies and satellite towns built. Today's city is much bigger than the one developed by the British. At present the British town along with the native is considered as the historic nucleus of the city of Karachi.

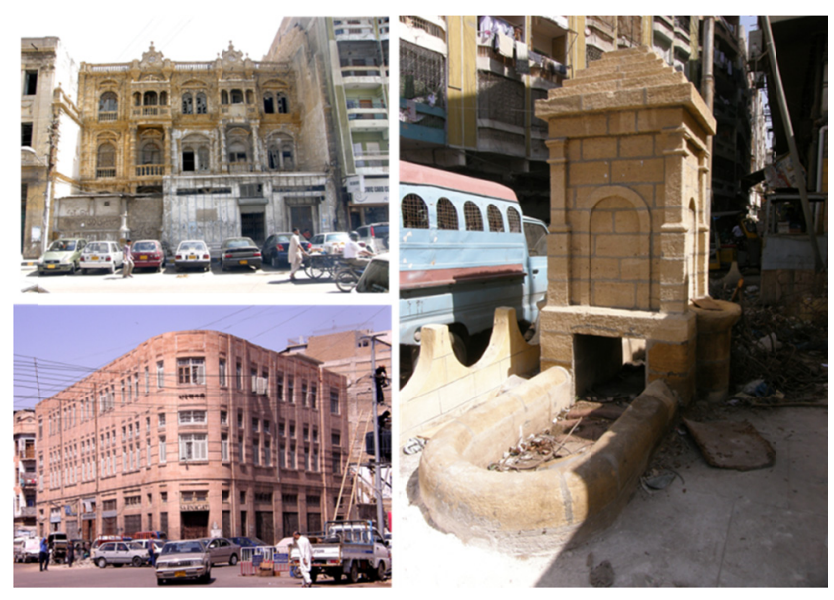

Fig. 2. Top left: Mendoza building in Rambagh quarter. Bottom left: Sernagati building (used to house British Council library), Right: Water trough.

\section{HISTORIC CITY CENTER - PRESENT DAY SITUATION}

The city received a sudden change of census after the Indian subcontinent partition, when Karachi became the capital of newly formed Pakistan in 1947. This change brought significant physical and cultural changes to the city. With the need of developing new institutions in the city, a secretariat for accommodating the federal government institutions was established in the Artillery Maidan quarter next to Saddar Bazaar. Most countries established their embassies in civil lines area. Also a university was established on what is now the Baba-i-Urdu road in the Arambagh quarter (formerly Rambagh 
quarter). The refugee population occupied most of the buildings abandoned by Hindus including public and religious in the native city and the open spaces in the cantonment and lines area near Sadder in a multi-class settlement structure. They included government officers, poets, artists, journalists and intellectuals. People from all walks of life made Karachi a multi-class high density metropolis with the Saddar Bazaar as a rising intellectual and entertainment center.

\section{A. Current Status of the Colonial Architecture in Karachi}

The Saddar Bazaar, which developed as the cultural hub of the city along with the rest of the quarters is now a victim of environmental degradation. The change of land and building use by laws has transformed the majority of the low rise historic structures into high rise plazas. The process of dilapidation started when the wealthier people moved out of center to the newly developed cooperative societies during the 1960s, leaving the earlier inhabited area as a transit area of the movement between the newly developed satellite towns of Korangi and Landhi and the work areas of the city [6]. The colonial buildings after the Indian subcontinent partition went through a lot of transformations, in the worst cases they were demolished. The demolition process stopped due to the enlistment system for the protected heritage in 1970s. Perhaps this act helped structures to sustain but the vandalism kept on going in the form of inappropriate changes in historic significance properties. For instance, the empress market along with a few nearby structures has survived despite the additions and modifications having largely retained the function for which they were originally constructed. Eduljee-Dinshaw dispensary building a few blocks away from the empress market has undergone several changes from the adding up of minor alterations to the addition of masses to its fabric. The same happened to the Khyber hotel building, which is a magnificent corner building with impressive arcaded openings on ground floor. It had gone through several alterations such as the closing of the arcade permanently, application of ceramic tiles over stone wall and so on.

\section{B. Urban Blight of the Heritage Properties in the Historic Center}

Based upon the study of the present conservation status of the heritage buildings, an analysis of the urban decay in the historic core of the city is made which illustrates how this decay eventually threatens the city's heritage properties. Within a decade of the independence the city extended its limits as new cooperative housing societies and satellite towns for the working class refugee population were established on the fringes of the city. This deprived the historic center of its elite class population as more influential and wealthier families in the refugee colonies shifted to those colonies leaving behind the historic buildings occupied by them earlier. On the one hand, when city grew outward for residential purpose, at the same time it grew inward from the commercial point of view. The major whole sale markets located within the city center extended their limits over time. As there was no more space for their extension they eventually occupied the historic structures and converted them into godowns and storage spaces, etc. Transportation crises emerged as to cater the distant located colonies and towns to the city center. Since there was no proper transportation network, the whole movement was through Saddar. This transformed Saddar into a transit camp, congested with people, badly maintained busses and badly maintained traffic [5]. In the 1960 the university was moved from the Rambagh quarter to its present location. This caused a rundown of student population and academic life in Rambagh. Moreover, amendments in the building by laws and land use regulations in 1972 caused a great deal of damage to the heritage buildings as well as open spaces. Earlier the plots which were eligible for ground floor construction are now qualified to go till $\mathrm{G}+8$ structures. This put a great threat to the historic structures. A large number of important heritage buildings are pulled down and replaced by new high and medium rise structures.

The changing demographic patterns have a great impact on the city. It has always been a threatening factor to the wellbeing of historic structures. Karachi being the metropolitan city and a commercial hub has to cater a large number of population. Apart from the annual rural urban migrations, the city has received three phases of the influx of refugees:

- Phase 1. Refugees from Indian subcontinent partition in 1947

- Phase 2. Refugees from Pakistan Bangladesh Partition in 1971

- Phase 3. Refugees from Afghan Russian war in 1980.

Apart from this the population tends to increase every year as the average household size increases. According to a recent research on the Population Division (2014), World Urbanization Prospects: the 2014 Review by the United Nations Department of Economics and Social Affairs, the city of Karachi is considered among world's top 10 populated cities. Its population is estimated to be $24,837,881$ in 2030 from 16,125,936 in 2014 [8]. Constant population growth with increasing economic pressures and least economic incentives exerts pressure on the buildings in order to fulfill the requirements of the dwellers, and under the inadequate law enforcement, the situation results in the poor state of conservation of architectural heritage.In the historic center of Karachi, exists an informal renting system called pugree or the good-will system. In this system the property is leased for over 99 years with a condition of bare minimum rental amount per month. Most of the historic premises in the historic core are rented on pugree that means they are rented and owned by different persons. The owner receives almost nothing whereas on the other hand the situation is pretty fair for the tenant who has to pay very little amount. The arrangement wields a great threat to the wellbeing of the architectural heritage. As the owner gets the minimal amount, it makes him least bothered about the well-being of his property and the tenant considers it as a rented property and not his own. In the end the property suffers.

\section{Repercussions of the Urban Blight in the Historic Center}

\section{1) Urban Densification}

The historic center of the city is densely populated with high rise structures giving a portrait of a thick concrete jungle 
with a limited number of surviving historic premises. The development pressure puts a great threat to those historic structures. Only the listed buildings are left untouched, the rest of the plots which once used to have low rise structures are now occupied by high rise skyscrapers.

\section{2) Encroachments}

The whole area is greatly encroached. Increasing household with lack of economic incentives puts pressure buildings in terms of modification to fulfill the requirements of the inhabitants. Limited availability of appropriate conservation expertise and the expensive techniques results in poor state of conservation of historic structures of the quarter. Moreover the increasing population exerts pressure on the public infrastructure and results in encroachments of roads, parks and the parking spaces etc. Due to corruption and several other reasons the anti-encroachment operations have failed to stop this process [6]. Figure 3 shows a few examples of encroachment and vandalism.

\section{3) Unwanted or Illegal Repairs}

The city of Karachi experienced an expansion with time in all historic quarters. The quarters have undergone several transformations both in functionality and appearance points of view. In center several residential apartment buildings due to increase in commercialization have acquired commercial activities on ground floors. Many religious buildings and open spaces are encroached to construct new buildings. However, the educational buildings have survived and sustained their original function so far. To keep the buildings still going and to meet the growing needs of space, these buildings have acquired a wide range of substandard alterations. The decaying process of these alterations is very rapid as these added structures are barely constructed with good quality material. At some places entire floors have been added to the existing structures without taking into account the stability of the structure to which they are attached to. The structures are therefore over loaded and perhaps cannot tolerate the dead load applied to them and may eventually collapse or crack severely [9]. Figure 4 shows one example.

\section{4) Traffic Evolution}

At the time of partition Saddar was linked to the rest of city by a network of trams that connected one end of the city to the other. The tramway was available for those who worked in the business district and the port. The major change occurred with the construction of new housing schemes that were outside Saddar. The tramway was not enough and a proper vehicular network was required. Bus services were added to meet the demand which resulted in increased vehicular traffic in the historic quarter. All bus services used to end in the vicinity of Empress Market since it was a landmark that had open spaces around it and also because it was at walking distance to the Pakistan Secretariat offices in Artillary Maidan quarter. With time Karachi grew more and new satellite towns developed on its fringes adding pressure on the transportation network. Because of its location, very large transit movement took place through Saddar. The city kept on growing and the transport agencies (government and private) could not cope with the huge increase in commuters. As a result the government introduced a free transport policy whereby any individual wishing to operate a bus could be given a route permit. Since no subsidies and bank loans or even any audit for the purchase of proper large busses were offered, individuals acquired route permits for affordable mini-buses and small coaches. With increase of population in years ahead mini busses became the most important transport mode in Karachi which is prevalent till today. This massive overcrowding of commuters and buses, in the absence of a rational transport plan for the city, resulted in the emergence of hawkers, encroachers, informal bus terminals and bus stops and an aggressive services sector to transport.

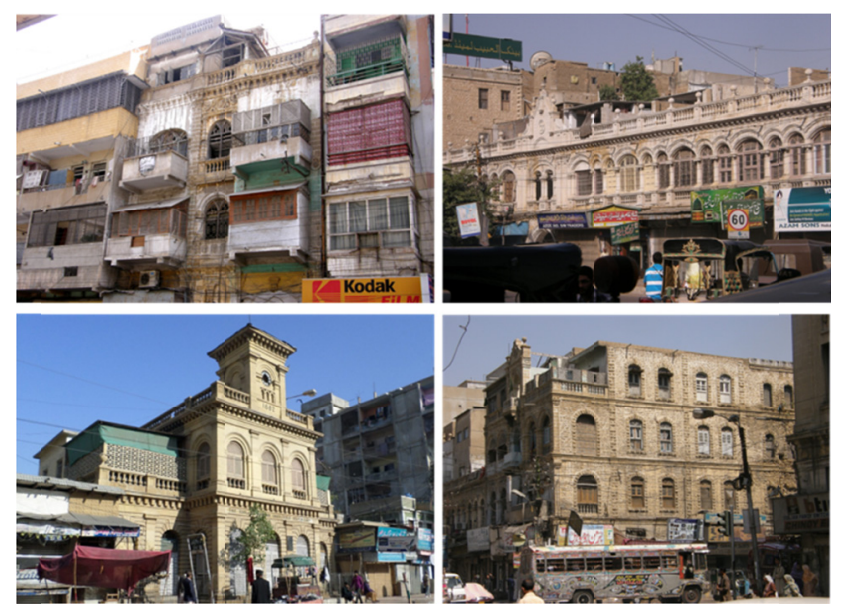

Fig. 3. Images showing encroachments and various forms of vandalism on historic buildings.

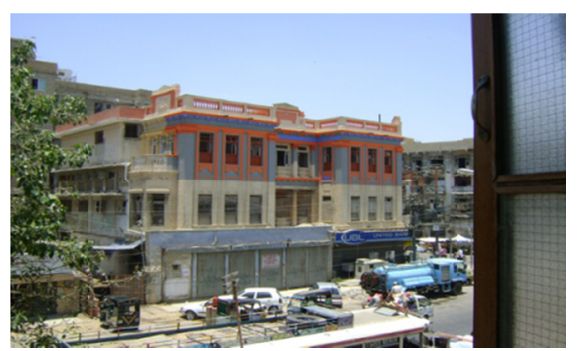

Fig. 4. Image showing unwanted repairs in form of application of paints as surface decoration over stone facade

\section{5) Commercialization Pressure}

During the past decades the function of most of the historic properties has been transformed from residential to commercial which puts the whole area under a great threat of further commercialization. The rate of demolition of historic structures and their replacement by high rise structures is alarmingly high. People prefer demolition as an easy way out rather than going for a systematic conservation strategy due to several reasons, financial capability being the most important. Demolishing old buildings is also an approach to earn easy revenue as antiquities of the demolished construction materials can be sold. The changing building regulations are also threatening the survival of the heritage properties of Karachi paving the way for new 
development projects. The economic changes, transformation of technology, modernism and the changing human behavior have played a great part in making old (historic) structures unwanted for present day world.

\section{6) Violence}

Violence in case of heritage properties manifests as arson attacks, vandalisms etc. The intentionally and maliciously setting fire to buildings, in order to get rid of them, is a common phenomenon. There have been cases in the past where precious buildings were burnt and then vandalized. Instead of being restored, the damaged edifices were dismantled to reconstruct the building. The process of reconstruction is only acceptable if the building had been damaged unintentionally but reconstructing the deliberately damaged buildings with a new objective can only be classified as vandalism.

\section{7) Political Pressure}

One of the very widespread and powerful causes of damage to historic buildings is political pressure. This type of damage is referred to a combination of damages such as the wall chalking in form of graffiti of the political slogans, party billboards defacing the building facades and party flags inserted in every corner. The image of the Empress market shown in the Figure 5 is a perfect description of this type of defacement.

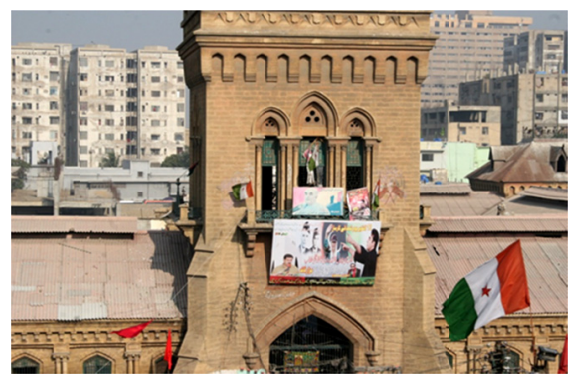

Fig. 5. Image showing graffiti and flags of political parties hung in Empress Market

\section{CONCLUSION}

Over time much of the architectural heritage has gone away and what remains is either in very dilapidated state or no longer functioning. The buildings which are structurally sound are still inhabited. The main conclusion drawn through this study is that the state of the urban blight to the heritage properties is consolidated with the non-prevailing situation of heritage law and the user conflicts. The ground realities like overpowering commercialization forces, lack of awareness and the ever increasing number of users make this subject even more perplexing. The best solution to mitigate this situation is to promote awareness on local level regarding the significance of historic premises because despite enduring severe changes the colonial architecture still offers preservation potential.

\section{REFERENCES}

[1] J. Ruskin, The Seven Lamps of Architecture, Courier Corporation, 1989

[2] H. Khuhro, A. Mooraf, Karachi; Megacity of our Times, 2nd Edition, Oxford University Press, 2010
[3] A. W. Hughes, Gazetteer of the Province of Sindh, George Bell and Sons, 1876

[4] A. Hasan, A. S. Polak, C. Polak, The Hawkers of Saddar Bazaar, Ushba Publishing International, 2008

[5] F. S. Aijazuddin, Historical Images of Pakistan, Ferozsons (Pvt) Ltd., 1992

[6] A. Hasan, Understanding Karachi, Planning \& Reform for the Future, City Press Publication, 1999

[7] H. Haroon, M. A. Baig, Karachi Under the Raj 1843-1947 Visions of Empire, Pakistan Herald Publications (PVT) Ltd, 2004

[8] United Nations Department of Economic and Social Affairs/Population Division, World Urbanization Prospects: The 2014 Revision, 2014

[9] K. V. Balen, "From Conservation Principles to Materialization (Or the Other Way Around: How Is Materialization Guided by Principles?)", Consolidation of Masonry: Advances in Materials Science and Restoration, Vol. 1, pp. 135-144, 2003 